\title{
First report VT isolate of citrus tristeza virus in veracruz, Mexico
}

\begin{abstract}
In the State of Veracruz, Mexico, citric fruits are among the most important fruits due to their high economic value in national and international markets. However, in the last months, combined symptoms of defoliation, yellowing and terminal-branches death have been observed; these cause gradual deterioration and low yield in the main citric species; these symptoms have been associated to Citrus Tristeza virus (CTV) like VT, and coincide with those reported in the literature: small fruits adhered to the plant, defoliation, and sudden death. By using the RT-PCR technique, plants positive to the VT, considered as severe, were detected. Incidence of positive samples ranged from $7 \%$ in Alamo to $43 \%$ in Tihuatlan. The fact that this VT isolate was found in seven of the eight studied locations explains the death rate observed in northern Veracruz.
\end{abstract}

Keywords: VT isolate, premature tree death, quick decline
Volume 4 Issue 3 - 2020

\author{
Rosalba Contreras-Maya,' Angel Villegas- \\ Monter ${ }^{\prime}$ \\ Fisiología Vegetal, Posgrado en Recursos Genéticos y \\ Productividad, Campus Montecillo, Colegio de Postgraduados, \\ México
}

Correspondence: Angel Villegas Monter, Colegio de Postgraduados, km 36.5 Carretera México-Texcoco, 56230, Texcoco, Estado de México, México, Email avillega@colpos.mx

Received: May 06, 2020 | Published: May 20, 2020

\section{Introduction}

In Veracruz, Mexico, citrus fruits are among the most important fruits due to their high economic value in national and international markets. During 2018 and 2019, a syndrome of yellowing, defoliation, necrosis of terminal-branches and sudden death of plants with small fruits remaining adhered to branches was observed in commercial Citrus spp. orchards. This syndrome, which causes low yield, quick decline, and premature tree deaths, has been associated with severe CTV like VT isolate, as reported by Besoain et al, Harper, BenítezGaleano et al. ${ }^{1-3}$ In La Concepción, in Tihuatlán municipality, Veracruz, a sudden death that caused population decline of up to $50 \%$ of $C$. sinensis trees in less than three months was observed in 2018. In 2019, orchards of $C$. sinensis, C. reticulata, C. latifolia, and $C$. paradisi located in Alamo, Castillo de Teayo, Cazones, Cuitláhuac, Martínez de la Torre, Papantla, Tihuatlán, and Tuxpan municipalities were sampled to determine the presence and distribution of VT isolate. Each sample consisted of four juvenile shoots collected 90 days after sprouting from the four cardinal points of each symptomatic tree; two-four samples were collected per orchard, and 66 orchards were analyzed.

The isolation of total RNA from citrus was obtained by central vein of leaves using protocol of Dellaporta DNA extraction adjusted to $2 \mathrm{mg}$ of tissue. Specific primers for VT (sense: TTT GAA AAT GGT GAT GAT TTC GCC GTC A, antisense: GAC ACC GGA ACT GCY TGA ACA GAA T) were utilized. Using the RT-PCR technique described by Roy et al. ${ }^{4}$ with modifications: For the reverse transcription reaction; mix $0.5 \mu \mathrm{L}$ of each primer $(100 \mathrm{pmol} / \mu \mathrm{L})$ with $4 \mu \mathrm{L}$ nuclease free water, and $2 \mu \mathrm{L} \mathrm{RNA}(200 \mathrm{ng} / \mu \mathrm{L})$ template of each sample were added to each Eppendorff tube and incubated at $72^{\circ} \mathrm{C}$ for $5 \mathrm{~min}$.

Subsequently, the tubes were placed on ice for $10 \mathrm{~min}$; afterwards, $4 \mu \mathrm{L}$ of the mixture containing $2.4 \mu \mathrm{L}$ Buffer $5 \mathrm{X}$ of M-MLV, $1 \mu \mathrm{LDTT}$ $10 \mathrm{mM}, 0.5 \mu \mathrm{L}$ dNTP's Mix, $0.1 \mu \mathrm{L}$ M-MLV Reverse Transcriptase (PROMEGA) were added to each sample, the tubes were incubate at $42^{\circ} \mathrm{C}$ for $60 \mathrm{~min}$ and $72^{\circ} \mathrm{C}$ for $10 \mathrm{~min}$. PCR was performed by adding, to each tube $9 \mu \mathrm{L}$ of mixture: $2 \mu \mathrm{L}$ Green buffer GoTaq DNA Polimerasa,
$0.4 \mu \mathrm{L}$ of $\mathrm{MgCl} 2(25 \mathrm{mM}), 0.2 \mu \mathrm{L}$ of dNTP's Mix, $0.6 \mu \mathrm{L}$ of each primer, $0.1 \mu \mathrm{L}$ of GoTaq DNA Polimerasa (PROMEGA), $5.1 \mu \mathrm{L}$ nuclease free water, and $2 \mu \mathrm{L}$ cDNA.

Positive plants to VT isolate of CTV were detected in seven municipalities, excepting Castillo de Teayo, and incidence ranged from $7 \%$ in Alamo to $43 \%$ in Tihuatlán. Blast analysis showed that representative sequences (GenBank accession nos. MN545966, MN545967, MN545968, MN545969, MN545970) had 93-97\% similarity to genotype VT (accession nos. KC517494.1, EU937519.1, KM679347.1). These results explain the high tree death rates observed in northern Veracruz and represent a great risk to the citrus industry's development, as occurred in Argentina (1930) and Brazil (1937) BarJoseph et al. ${ }^{5}$ also implies that the efficacy of mexican regulations (NOM-031-FITO-2000 and NOM-079-FITO-2002) established to avoid CTV dispersion must be revised.

These results are concerning because the disease is rapidly advancing; besides, Veracruz is not the only affected producer state; in Nuevo Leon, Colima, Baja California, and Tamaulipas severe cases have been detected. ${ }^{6}$ The disease is still dispersing; in addition, citric growers in Mexico use sour orange rootstocks (C. aurantium), which is more susceptible to $\mathrm{CTV}^{7}$

\section{Conclusion}

The present molecular study is the first report of CTV like VT in various citric species in the main producer and exporting communities in the state of Veracruz, Mexico.

The potential for future citrus losses from CTV is much greater than has been seen to date. Therefore, the development of means to protect citrus groves from aggressive isolates.

Cross protection with attenuated isolates is the most successful approach to reduce the effect of viral disease and is an option that must be implemented in Mexico in the face of the imminent epidemic as a strategy that must be developed in the country as an alternative.

\section{Acknowledgments}

None. 


\section{Conflicts of interest}

Authors declare no conflict of interest exists.

\section{References}

1. Besoain X, Bertolini E, Camps R, et al. Aggressive Citrus tristeza virus isolates in Chile are MCA13-positive and VT type, while mild isolates are MCA13-negative and T30 type. Ciencia e Investigación Agraria. 2015;42(2):251-262.

2. Harper SJ. Citrus tristeza virus: evolution of complex and varied genotypic groups. Frontienrs in Microbiology. 2013; 4(93):1-18.

3. Benítez-Galeano MJ, Rubio L, Bertalmío A, et al. Phylogenetic studies of the three RNA silencing suppressor genes of south american CTV isolates reveal the circulation of a novel genetic lineage. Viruses. 2015;7:41524168 .
4. Roy A, Ananthakrishnan G, Hartung JS, et al. Development and application of a multiplex reverse-transcription polymerase chain reaction assay for screening a global collection of citrus tristeza virus isolates. Phytopathology. 2010;100(10):1077-1088.

5. Bar-Joseph M, Marcus R, Lee RF. The continuous challenge of citrus tristeza virus control. Annual Review Phytopathology. 1989;27:291-316.

6. Herrera-Isidron L, Ochoa SJC, Rivera BR, et al. Sequence diversity on four ORFs of citrus tristeza virus correlates with pathogenicity. Virology Journal. 2009;6:116.

7. Silva-Vara S, Peña-del Río MA, Peña-Martínez R, et al. Distribución del virus de la tristeza en tres plantaciones comerciales de cítricos del estado de Nuevo León, México. Agrociencia. 2001;35:441-450. 